\title{
New Urbanism and sense of community in new Egyptian settlements: case study - EI Sherouq city, Egypt
}

\author{
S. Shafik \& S. El Bayar \\ Arab Academy for Science and Technology and Maritime Transport, \\ Department of Architectural Engineering and Environmental Design, \\ Alexandria, Egypt
}

\begin{abstract}
In the past, each street and alley had a story to tell, each having its own flavor. Different neighborhoods reflected the cultures and beliefs of different people. Due to industrialization, the rise of car dependence, and technological advancement, cities and towns' edges and centers have faded away because of urban sprawl. New communities have emerged far away from the heart of the city. These new communities lack identity, sense of community and suffer problems such as social exclusion. New Urbanism emerged as a reaction to undo and avoid the negative impacts of urban sprawl. This research aims to check which New Urbanism principles are already applied and which can be applied to Panorama El Sherouq neighborhood in El Sherouq City, Egypt. The scope of this paper will focus on the relationship between New Urbanism principles and sense of community. It highlights New Urbanism principles and clarifies sense of community in an analytical example. Finally, this research aims to evaluate the sense of community in Panorama El Sherouq and to achieve a set of recommendations to apply New Urbanism principles to enhance sense of community.
\end{abstract}

Keywords: New Urbanism, sense of community, neotraditionalism.

\section{Introduction}

In old Egyptian neighborhoods, people were attached to their neighborhood as they built up memories of growing up, memories of their ancestors that once lived there, and memories of warm neighbors that looked for one another. 
Neighborhoods play a big role in shaping one's identity and sense of community. A well planned neighborhood allows people to bond together.

Due to industrialization, the urban population increased according to the census of Egypt in various years [1]. Peasants immigrated from the rural to the urban in search of better job opportunities. Cities and towns' edges and centers faded away with the urban sprawl. The cities identity and historical background are erased by new unplanned developments. Moreover, people focus on their own competing fast paced life, that they become isolated from one another. Thus, sense of community started to fade away.

Achieving urban sustainability is a major obstacle to many cities and towns because of the growing urban sprawl. New Urbanism emerged as a reaction to undo and avoid the negative impacts of urban sprawl. The main objective of New Urbanism is the promotion of sense of community [2]. Along with sense of community, there were other social goals like social equity and common good. Questions arose whether or not New Urbanism is actually capable of promoting sense of community in new settlements and whether or not New Urbanism principles could be adopted in New Egyptian settlements.

\section{Definition of New Urbanism}

New Urbanism or neotraditionalism is a western movement emerged in the nineteenth century as a reaction to the unplanned urban sprawl. New urbanism is identified as an umbrella term for design tenets of Traditional Neighborhood Development (TND) and Transit Oriented Development (TOD) [2]. TND principles are inspired from the urban form used in centuries before the invention of automobiles. In addition, TOD is dense development of housing and commercial units taking into consideration transportation connections [3].

New Urbanism principles is concerned with walkable, connected, mixed-use and diverse neighborhoods. It supports the traditional neighborhood structure and the quality of architecture and urban design. Other principles include: mixed housing, increased density, narrow streets, and discernible neighborhood center [4].

\section{New Urbanism Movement}

Founded in 1993, a group of architects formed the Congress of New Urbanism (CNU) seeking to create principles based on their previous works to create better performing neighborhoods. CNU held many congresses to demonstrate goals and principles of New Urbanism. Their goal is to reform the public policy to support the restoration of existing urban centers and towns within metropolitan regions, the reconfiguration of sprawling suburbs, taking into consideration the natural environment, and preservation of the built heritage. According to the CNU, public policy should be formed to support diverse uses and population in neighborhoods, communities should be designed for pedestrian, transit, and automobiles. Not only that, but communities should embrace public spaces and 
civic institutions. Moreover, urban space should be shaped by architecture and landscape that reflect local history, climate, ecology, and building practice [5].

In 2000, the CNU outlined the principles in the Charter of New Urbanism. The charter includes principles to guide public policy development practice, urban planning, and design. The principles are distributed into three scales: The region: Metropolis, city, and town; the neighborhood, the district, and the corridor; the block, the street, and the building [5].

\section{Definition of sense of community}

Based on Joseph R Gusfield, the term community covers two aspects: the territorial and geographical part of the community like neighborhood, town, and city. The second aspect is relational which is related to the quality of human relationships. Gusfield stated that the two aspects are interdependent to sense of community [6]. On the other hand, Durkheim stated that community develops around interests and skills more than environment [7].

The most widely accepted definition to date for sense of community by David W. MacMillan and David M. Chavis is "a feeling that members have of belonging, a feeling that members matter to one another and to the group, and a shared faith that members' needs will be met through their commitment to be together" [8]. The definition includes four elements: membership, influence, integration and fulfillment of needs, and shared emotional connection. The correlated four elements make up the definition of sense of community.

Based on Chavis and MacMillan [8] membership is feeling of belonging or personal relatedness among residents. It is bounded by language, dress, and rituals. Boundaries are created among people in fear of rejection for being different. Membership grants emotional safety, sense of belonging, identification, feeling of acceptance, and the willingness to sacrifice for a group of members. Another membership attribute is personal investment. Members of a community have a common symbol system identified by a logo, landmark, or an architectural style. Nonetheless, members are attracted to a community in which they feel that they are influential.

Chavis and MacMillan [8] stated that influence is a sense of mattering of making a difference to a group and group mattering to its member. Research proves that one can influence others taking into consideration needs, values, and opinions of other members. People feel they have influence through leadership role even if it was indirect. Group cohesiveness is determined by community influence and conformity. However, group may lay pressures on members for conformity causing into negative outcomes in the community. A balanced community is where members don't give up their own choices for conformity and yet be accepted by the other contradicting members. In addition, participation leads to greater "ownership of the community, greater satisfaction, and greater cohesion between members". Moreover, influence of a member on the community and the influence of the community on a member function parallel to each other to achieve community cohesiveness. 
Another key element of sense community according to Chavis and MacMillan [8] is integration and fulfillment of needs or in other words reinforcement. A community should be able to fit different members together so that they meet other member's needs while meeting their own. Community should reward members through status of membership, success of the community and competence of other members to reinforce sense of community. Individuals are attracted to communities that offer them the most. Apart from the survival needs, there are the shared values where a community is able to organize and prioritize its need to be fulfilled through activities. Individuals with shared values, beliefs, priorities, and needs form cohesive communities.

As for the emotional connection, Chavis and MacMillan [8] stated that individuals that share history strengthen the community. Contact hypothesis states that the more members of the community interact, the more likely they are close and the more positive the quality of interaction, the stronger the bond between members is. Not only had that, but sharing important events bring people closer together. Events shouldn't be ambiguous and left unresolved, closure to events impacts cohesiveness. Moreover, personal investment among members enhances community cohesiveness. Additionally, honoring members for positive impacts create emotional connections between different members. Another attribute enhancing the emotional connection is the spiritual bond found in many religious communities.

Other researchers such as Buckner describe sense of community as "the sense of belongingness, fellowship, "we-ness", identity, etc., experienced in the context of functional (group) or geographically based collective” [9]. Another definition by Glynn identified sense of community's main elements as homogeneity, interdependence, shared responsibility, face-to-face relationships, and common goals [10]. Later on, Joranko stated the importance of connection, belonging, support, safety, empowerment, and participation to sense of community [11]. Talen stated that there are other elements that impact sense of community such as homogeneity, income, gender, and education [2].

Based on the previous discussion, Table 1 shows that some elements mentioned by Buckner, Glynn, and Joranko are similar to each other and can fall under the four elements proposed by MacMillan and Chavis. In addition, there are other points introduced by them that are not included in the four elements by MacMillan and Chavis.

Based on MacMillan's and Chavis definition and theories of sense of community, a Chavis, Hogge, McMillan and Wandersman [12] developed Sense of Community Index (SCI) to measure sense of community. It was criticized on the limited variability of its true or false response. Later on, a research of immigrant integration in a Western State provided a Sense of Community Index version 2 (SCI-2) which covered all elements of sense of community using a Likert like scale. In this paper, SCI-2 will be implemented to evaluate the degree of sense of community in Panorama El Sherouq. 
Table 1: $\quad$ Sense of community elements and their attributes.

\begin{tabular}{|c|c|}
\hline $\begin{array}{c}\text { Sense of community } \\
\text { elements }\end{array}$ & Attributes \\
\hline Membership: & $\begin{array}{ll}\text { - } & \text { Emotional Safety } \\
\text { - } & \text { Boundaries } \\
\text { - } & \text { Sense of Belonging } \\
\text { - } & \text { Personification Investment } \\
\text { - } & \text { Common Symbol System } \\
\text { - } & \text { Feeling of Acceptance } \\
\text { - } & \text { Sacrifice } \\
\text { Identity }\end{array}$ \\
\hline Influence: & $\begin{array}{ll}\text { - } & \text { Influence of an individual on a community } \\
\text { - } & \text { Leadership } \\
\text { - } & \text { Influence of community on individual } \\
\text { - } & \text { Partormity } \\
\text { - } & \text { Empowermention } \\
\text { - } & \text { Shared Responsibility }\end{array}$ \\
\hline $\begin{array}{l}\text { Integration and Fulfillment } \\
\text { of Needs: }\end{array}$ & 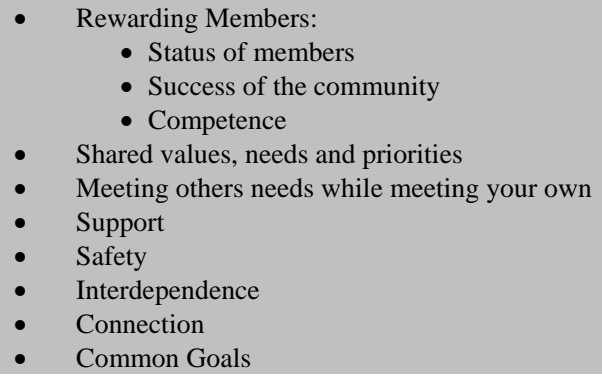 \\
\hline $\begin{array}{l}\text { Shared } \\
\text { Connection: }\end{array}$ & $\begin{array}{ll}\text { - } & \text { Shared History } \\
\text { - } & \text { Interaction \& Quality of Interaction } \\
\text { - } & \text { Events Closure } \\
\text { - } & \text { Shared Important Events } \\
\text { - } & \text { Investment } \\
\text { - } & \text { Honoring Members } \\
\text { - } & \text { Spiritual Bond } \\
\text { - } & \text { Fellowship } \\
\text { - } & \text { Face to Face relationships }\end{array}$ \\
\hline Demographic features: & $\begin{array}{ll}\text { - } & \text { Homogeneity } \\
\text { - } & \text { Age } \\
\text { - } & \text { Eender } \\
\end{array}$ \\
\hline
\end{tabular}

\section{New Urbanism and sense of community}

New Urbanists claim that the built environment can foster sense of community. Table 2 shows the relationship between New Urbanism's Charter and the five elements of sense of community derived from the previous discussion. 
Table 2: Relationship between New Urbanism's charter and sense of community.

\begin{tabular}{|c|c|}
\hline Charter principle & Sense of community \\
\hline \multicolumn{2}{|l|}{ The region: Metropolis, city, and town } \\
\hline $\begin{array}{l}\text { The physical organization of the region should be } \\
\text { supported by a framework of transportation alternatives. } \\
\text { Transit, pedestrian, and bicycle systems should } \\
\text { maximize access and mobility throughout the region } \\
\text { while reducing dependence upon the automobile. }\end{array}$ & $\begin{array}{l}\text { Shared Emotional Connection: } \\
\text { interaction, face to face relationships } \\
\text { Integration and fulfillment of Needs: } \\
\text { connection, meeting other needs while } \\
\text { meeting your own }\end{array}$ \\
\hline \multicolumn{2}{|l|}{ The neighborhood, the district, and the corridor } \\
\hline $\begin{array}{l}\text { The neighborhood, the district, and the corridor are the } \\
\text { essential elements of development and redevelopment in } \\
\text { the metropolis. They form identifiable areas that } \\
\text { encourage citizens to take responsibility for their } \\
\text { maintenance and evolution. }\end{array}$ & $\begin{array}{l}\text { Membership: personal investment } \\
\text { Influence: participation, shared } \\
\text { responsibility }\end{array}$ \\
\hline
\end{tabular}

Neighborhoods should be compact, pedestrian friendly, and mixed-use. Districts generally emphasize a special single use, and should follow the principles of neighborhood design when possible. Corridors are regional connectors of neighborhoods and districts; they range from boulevards and rail lines to rivers and parkways.

Many activities of daily living should occur within walking distance, allowing independence to those who do not drive especially the elderly and the young. Interconnected networks of streets should be designed to encourage walking, reduce the number and length of automobile trips, and conserve energy.

Transit corridors, when properly planned and coordinated, can help organize metropolitan structure and revitalize urban centers. In contrast, highway corridors should not displace investment from existing centers.

Appropriate building densities and land uses should be within walking distance of transit stops, permitting public transit to become a viable alternative to the automobile.

Integration and Fulfillment of Needs: shared needs, connection

Shared Emotional Connection: interaction, face to face relationships

Shared Emotional Connection: interaction, face to face relationships

Integration and Fulfillment of Needs: interdependence, needs connection

Shared Emotional Connection: interaction, face to face relationships

Integration and Fulfillment of Needs: connection

Shared Emotional Connection: interaction, face to face relationships

Integration and Fulfillment of Needs: connection

Concentrations of civic, institutional, and commercial activity should be embedded in neighborhoods and districts, not isolated in remote, single-use complexes. Schools should be sized and located to enable children to Integration and Fulfillments of needs: reinforcement of needs walk or bicycle to them.

A range of parks, from tot-lots and village greens to ballfields and community gardens, should be distributed within neighborhoods. Conservation areas and open lands should be used to define and connect different neighbor- hoods and districts.

Shared emotional Connection: interaction, face to face relationships

Integration and Fulfillment of Needs: connection

The block, the street, and the building

Streets and squares should be safe, comfort- able, and interesting to the pedestrian. Properly configured, they encourage walking and enable neighbors to know each other and protect their communities.

Integration and Fulfillment of Needs: connection, safety

Influence: participation 
Table 2: $\quad$ (Continued).

\begin{tabular}{ll}
\hline \multicolumn{1}{c}{ Charter principle } & \multicolumn{1}{c}{ Sense of community } \\
\hline $\begin{array}{l}\text { Civic buildings and public gathering places require } \\
\text { important sites to reinforce community identity and the } \\
\text { culture of democracy. They deserve distinctive form, } \\
\text { because their role is different from that of other } \\
\text { buildings and places that constitute the fabric of the city. }\end{array}$ & Membership: common symbol \\
\hline $\begin{array}{l}\text { Preservation and renewal of historic buildings, districts, } \\
\text { and landscapes affirm the continuity and evolution of } \\
\text { urban society. }\end{array}$ & $\begin{array}{l}\text { Membership: common symbol } \\
\text { system, identity }\end{array}$ \\
\hline
\end{tabular}

\section{Analytical example: Kentlands and Orchard Village}

Kim Joongsub [13] made a comparative case study between two suburbs Kentlands and Orchard Village; both suburbs lie in Gaithersburg, USA. Kentland is 352 acre development designed in 1988 by Andres Duany and Elizabeth Plater-Zyberk (among the co-founders of New Urbanism). Kentlands is planned for around 1,800 residential units and around 800,000 square feet of retail and office space. It includes mix of housing types, retail, office, civic uses within the community; and diverse high dense neighborhoods configured in narrow grid streets. There are a few cul-de-sacs and a network of alleys, small land lots with narrow setbacks and traditional architecture elements. Garages face alleys rather than streets. Public open spaces cover an area of 100 acres that include tot lots, common greens, lakes, and parks. Each neighborhood has a central common green and the design respects local topography and landscape.

Similar to Kentlands, Orchard Village is a suburban community with similar average single family home prices to Kentlands. The average household income, age of development, and housing types are also similar to those of Kentlands. Unlike Kentlands, Orchard Village has curvilinear streets and lots of cul-de-sacs. Similar housing types lie on large land lots and lacks retail facilities. In addition, it doesn't include common central greens, landmark, and doesn't reflect traditional architecture. Orchard Village has fewer sidewalks than Kentlands, bigger setbacks, and lower housing density [13].

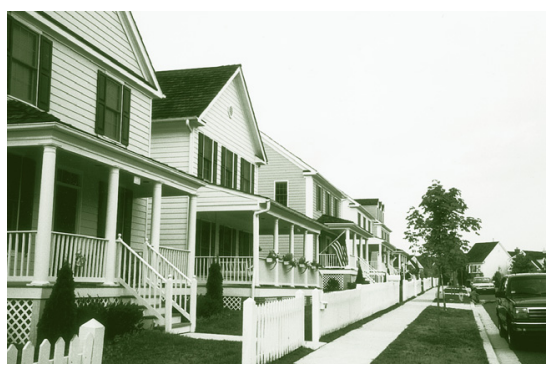

Figure 1: $\quad$ Kentlands [13].

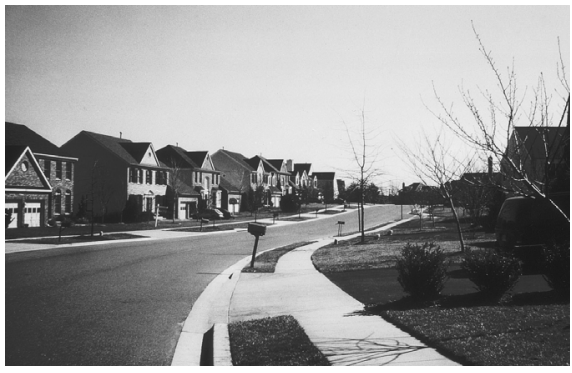

Figure 2: $\quad$ Orchard Village [13]. 
Joongsub [13] performed a survey that covers four points: pedestrianism, community attachment, social interaction, and community identity. Pedestrianism and social interaction fall under the shared emotional connection because it promotes face to face relationships. Community identity and community attachment fall under membership.

Respondents to the survey [13] stated that they find Kentlands as convenient, fun, and pleasant to explore. On the other hand, respondents from Orchard Village stated the lack of sidewalks discouraged walking. In addition, Kentlands' respondents referred to it as home and they don't plan to move elsewhere. They also mentioned the traditional architecture style and traditional town planning strengthened community identity. Respondents from Orchard Village did not complain nor showed strong bonding to it. Moving on to the social interaction, Kentlands supports sense of community which is facilitated by the physical environment. There were many positive responses about social interaction from Kentlands with a few negative responses coming from apartments and condominiums residents as they felt physically isolated from the rest of the community. Orchard Village respondents also expressed satisfaction with the level of social interaction but many wished for a stronger social interaction like the one at Kentlands. The lack of tot lots, the unfit clubhouse size, and lack of participation in community activities marked a weakness in Orchard Village. However, cul-de-sacs facilitated social interaction on an intimate scale but not beyond its boundaries. As for the community identity, Kentlands residents expressed that they had a strong physical character and identity which makes them proud of the environment they live in. Respondents of Orchard Village pointed out many positive aspects about it but none described it as attractive or distinctive. This comparison reveals the high degree of sense of community enjoyed by Kentland's residents due to the built environment that follow New Urbanism principles [13].

\section{Case study: El Sherouq city, Egypt}

El-Sherouq City lies on the outskirts of Cairo, Egypt. It is $35 \mathrm{~km}$ away from the center of Cairo and covers an area of 12,454 acres. Initially, it was built to provide residence away from the crowded city and stay connected through a network of highways. This factor contributed to the use of private cars as the main transportation which led to the isolation of Sherouq City's residents. Among Cairenes, Sherouq City is known as "Madinet el Ashbah" which means the city of ghosts. Panorama El Sherouq neighborhood lies on the western part of El Sherouq City was chosen to evaluate its sense of community according SCI-2. The neighborhood is composed of similar four story buildings with different sized apartments. Panorama Mall lies in the corner of the neighborhood and includes a supermarket, a bank, hypermarket, and miscellaneous stores. Buildings are configured around parks and streets are lined with trees.

Although Panorama El Sherouq has potentials of a mall within a quarter of a kilometer, which is considered a walkable distance based on Cairo's rough weather, it lacks many elements that can promote a stronger sense of community. 


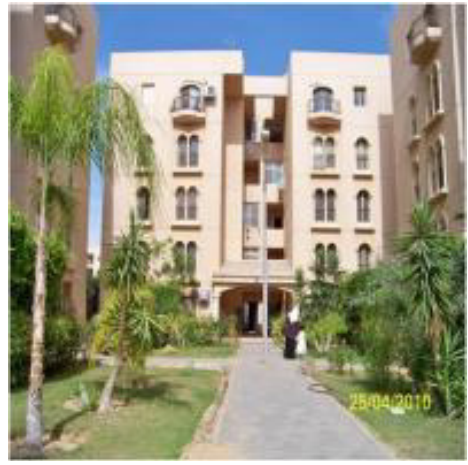

Figure 3: Buildings approach in Panorama El Sherouq. (Source: www.dyarna.com.)

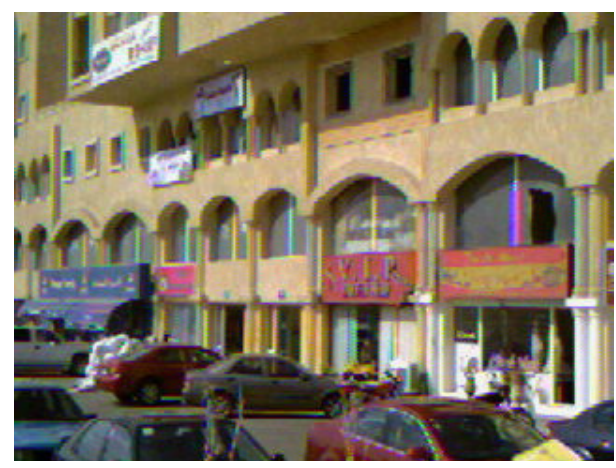

Figure 4: $\quad$ Panorama Mall. (Source: www.aswaqalex.com/.)

The Panorama Mall is underdeveloped and many stores did not open yet. On top of that, the neighborhood lacks gathering places such as squares and on street cafeterias, and limited mixed-use. Although it includes pocket parks, individuals don't visit it often due to the lack of activities there. Members of Panorama El Sherouq travel back to Cairo on weekends to go to recreational areas such as the movies or a nice restaurant. They depend on their own cars because of the lack of public transportation. All the buildings are similar in form. Members feel safe walking in the streets because of the security and enjoy the quiet atmosphere.

A SCI-2 questionnaire was distributed to members of Panorama El Sherouq. The questionnaire included 24 questions. Every 6 questions cover one of the four elements of sense of community. Respondents had a variety of answers to choose from starting from not at all, somewhat, most of the times, and completely. For the 24 questions:

\section{Not at All =0, Somewhat $=1$, Mostly $=2$, Completely $=3$ \\ Total Sense of Community Index = Sum of Q1 to Q24}

The first element, membership, scored an average of 13 points out of 18 . The factors with the least points were emotional safety and identification as shown in Figure 5. Respondents stated that they can barely recognize their neighbors and that many found it hard to trust other community members.

The influence factors with the lowest average points are the presence of good leaders in the community, whether the community can influence members and whether members can influence their community. These results are illustrated in Figure 6. Influence scored an average of 11 out of 18. Many members complained that no one pays attention to the community problems. 


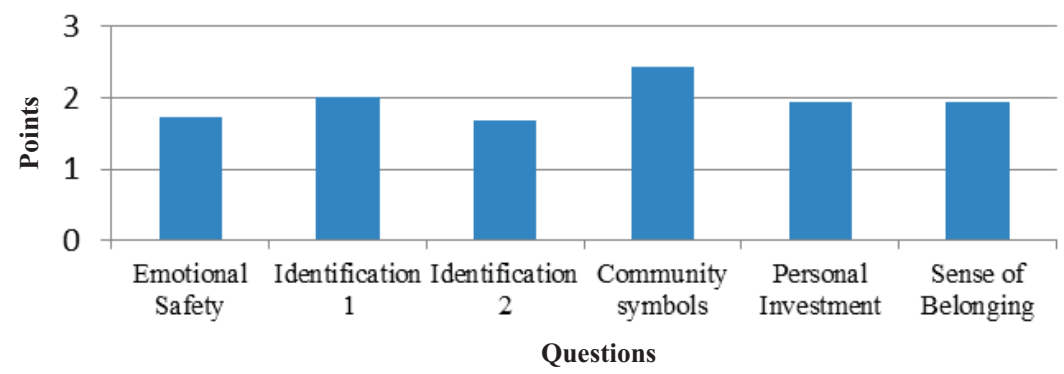

Figure 5: Membership.

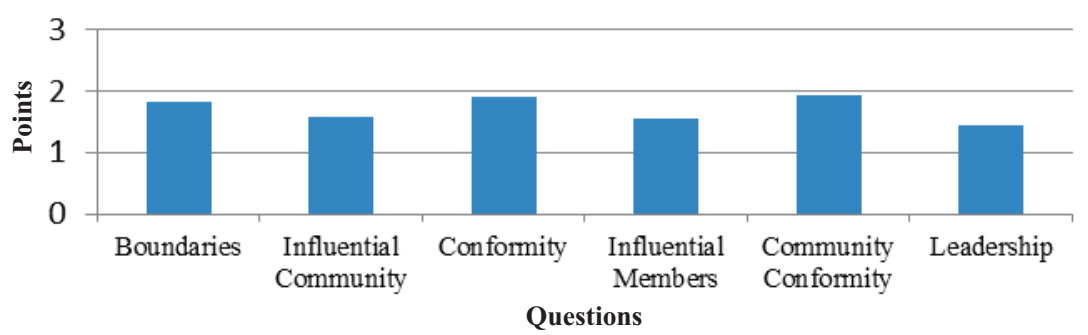

Figure 6: Influence.

The element integration and fulfillment of needs is illustrated in Figure 7. It scored an average of 11 out of 18 points. During the questionnaire, respondents claimed that the daily basic needs such as food and drinks are available in Panorama Mall. However, they still needed to go back to Cairo on weekends to hang out with their friends and families in gathering spaces such as the mall, cafes, and restaurants.

Figure 8 shows the different factors that are linked to shared emotional connection. The lowest issues are members spending time together and caring for each other. It scored an average of 13 out of 18 points. Members claimed that the neighborhood lacks viable gathering spaces.

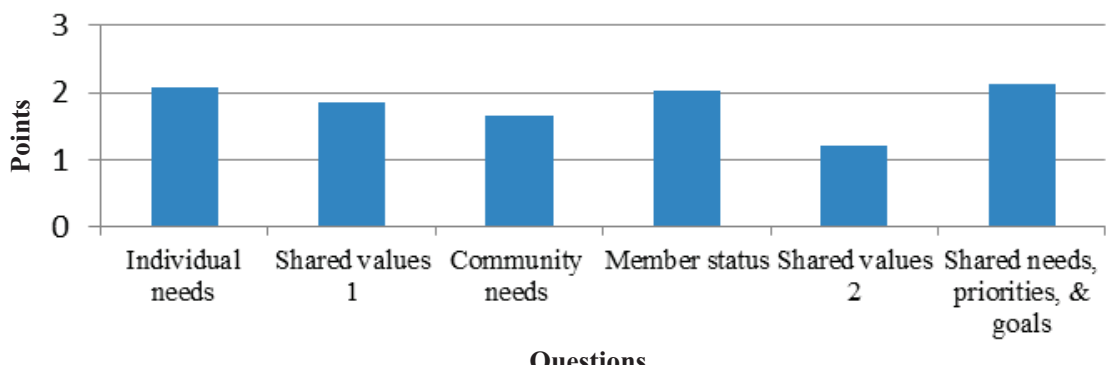

Figure 7: Integration and fulfillment of needs. 


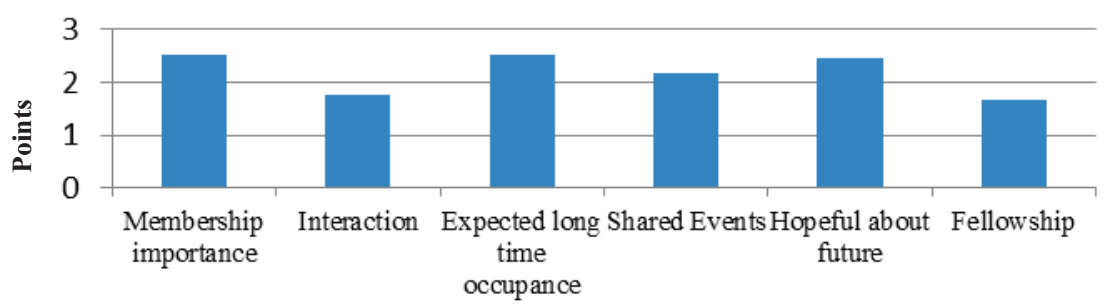

Questions

Figure 8: $\quad$ Shared emotional connection.

The average Sense of Community Index for Panorama El Sherouq is 48 out of 72. Panorama El Sherouq weaknesses lie in the lack of public transportation and viable gathering spaces. These weaknesses diluted the rich face to face social interaction. In order to enhance the sense of community in Panorama El Sherouq, the physical design of the built environment needs to be enhanced as well to be able to foster rich face to face social interaction. This could be reached through gathering spaces like parks robust with activities for kids, teenagers, and adults. In addition, public transportation needs to be integrated within El Sherouq City to connect different neighbourhoods within El Sherouq City with each other and connect it to Cairo as well. However, there are factors other than the physical design that play a role in sense of community like age, expected tenure, gender, education, and homogeneity.

\section{Conclusion}

The built environment may not directly impact sense of community but it can encourage other attributes that can enhance it. New Urbanism includes many of these attributes in their design principles. This is proved in Kentlands community, where the New Urbanism principles impacted sense of community. This shows that there is a link between the built environment of the community and the psychological sense of community. However, there are other contributors such as the demographics and sharing important events such as disasters that can bring members closer together.

In order to enhance the sense of community in new Egyptian settlements, the configuration of buildings should foster social activities that allow rich face to face social interaction. The design of the neighborhood should be walkable, mixed use and include gathering spaces such as parks. These design principles are embedded within New Urbanism.

Further research can be carried out on what extent does traditional neighborhood design principles embedded within New Urbanism impact sense of community. Further research may be investigated on measuring and evaluating sense of community in other new Egyptian settlements. Sense of community is a major key issue in sustainability. For this reason practitioners should consider the relationship between sense of community and the built environment. 


\section{References}

[1] Sims, D., Urban Slums Report: The Case of Cairo, Egypt, Cairo, 2003.

[2] Talen, E., Sense of community and neighborhood form: An assessment of the social doctrine of new urbanism, Urban Studies, 36(8), pp. 1361-1379, 1999.

[3] Port, A., Application of Selected New Urbanist Principles To Residential Infill Developments in Mature Suburbs of Greater Boston, Massachussetts, 2004.

[4] Duany, A. \& Plater-Zyberk, E., Towns and Town-Making Principles, New York: Rizzoli, 1991.

[5] Congress of the New Urbanism, Charter of the New Urbanism. http://www.cnu.org/.

[6] Gusfield, J. R. , The community: A critical response, New York: Harper Colophon, 1975.

[7] Durkheim, E., The division of labor in society, New York: Free Press of Glencoe, 1964.

[8] Chavis, D. M. \& MacMillan, D. W., Sense of Community: A Definition and Theory. Journal of Community and Psychology, 14(1), pp. 6-23, 1986.

[9] Buckner, J., The Development of an Instrument to Measure Neighbourhood Cohesion. American Journal of Community Psychology, 16(6), pp. 771791, 1988.

[10] Glynn, T. J., Psychological Sense of Community: Measurement and Application. Human Relations, 34(7), pp. 789-818, 1981.

[11] Joranko, D., The Sense of Community on a Racially Integrated Residential Block in Lansing, Michigan, https://www.msu.edu.

[12] Community Science, Community Science Publications, www.communityscience.com.

[13] Joongsub, K., Creating Community: Does the Kentlands Live up to Its Goals? Places Journal, 13(2), pp. 48-55, 2000. 